\title{
Uji Daya Hambat Ekstrak Bunga Kembang Sepatu (Hibiscus rosa-sinensis L.) terhadap Pertumbuhan Bakteri Streptococcus mutans
}

\author{
Henaldy Parengkuan, ${ }^{1}$ Vonny N. S. Wowor, ${ }^{1}$ Damajanty H. C. Pangemanan ${ }^{2}$ \\ ${ }^{1}$ Program Studi Pendidikan Dokter Gigi Fakultas Kedokteran Universitas Sam Ratulangi \\ Manado \\ ${ }^{2}$ Bagian Fisiologi Fakultas Kedokteran Universitas Sam Ratulangi Manado \\ Email: aldyparengkuan@gmail.com
}

\begin{abstract}
Hibiscus plant (Hibiscus rosa-sinensis L.) contains several antibacterial compounds such as tannin, alkaloids, triterpenoids, cyanidine, glycosides, and quercetin. One alternative to deal with diseases such as caries caused by bacterial infections is the use of hibiscus (Hibiscus rosa-sinensis L.). This study was aimed to determine the inhibitory effect of hibiscus flower extract on the growth of Streptococcus mutans bacteria causing caries. This was an experimental study with the modified Kirby-Bauer method using disks. Hibiscus flowers were obtained from Kotamobagu, North Sulawesi, and extracted by using maceration method and $96 \%$ ethanol as the solvent. The results showed that the total inhibition zone diameter resulted by hibiscus flower extract in five Petri dishes was $23.5 \mathrm{~mm}$ with an average of $4.6 \mathrm{~mm}$. In conclusion, hibiscus flower extract had a weak inhibitory effect on the growth of Streptococcus mutans.
\end{abstract}

Keywords: Hibiscus rosa-sinensis L., Streptococcus mutans, caries, inhibition zone

\begin{abstract}
Abstrak: Tanaman kembang sepatu (Hibiscus rosa-sinensis L.) mengandung beberapa senyawa yang bersifat antibakteri seperti tannin, alkaloid, triterpenoid, sianidin, glikosida, kuersetin. Salah satu alternatif untuk menanggulangi infeksi bakteri seperti karies yaitu dengan penggunaan bunga kembang sepatu (Hibiscus rosa-sinensis L.). Penelitian ini bertujuan untuk mengetahui daya hambat ekstrak bunga kembang sepatu terhadap pertumbuhan bakteri Streptococcus mutans penyebab karies gigi. Jenis penelitian ialah eksperimental dengan metode modifikasi Kirby-bauer menggunakan cakram. Bunga kembang sepatu diperoleh dari daerah Kotamobagu, Sulawesi Utara, dan diekstraksi dengan metode maserasi menggunakan etanol $96 \%$ sebagai pelarut. Hasil penelitian menunjukkan total diameter zona hambat yang dihasilkan ekstrak daun bunga sepatu pada lima cawan Petri sebesar 23,5 mm dengan nilai rerata 4,6 $\mathrm{mm}$. Simpulan penelitian ini ialah ekstrak bunga kembang sepatu memiliki daya hambat terhadap pertumbuhan bakteri Streptococcus mutans yang tergolong lemah.

Kata kunci: bunga kembang sepatu, Streptococcus mutans, karies, daya hambat
\end{abstract}

\section{PENDAHULUAN}

Kesehatan gigi dan mulut merupakan hal yang sangat penting dan patut diperhatikan, karena dalam rongga mulut terdapat berbagai macam bakteri yang dapat menyebabkan masalah bagi kesehatan gigi dan mulut, dan kesehatan tubuh umumnya. Akibat infeksi yang disebabkan oleh bakteri ini tidak hanya berupa karies gigi tetapi juga dapat menyerang jaringan periodontal atau jaringan pendukung gigi dan bahkan menyebar melalui aliran darah ke organ-organ tubuh penting lainnya. Menurut hasil Riset Kesehatan Dasar (Riskesdas) tahun 2018, prevalensi nasional masalah kesehatan gigi dan mulut sebesar $57,6 \%{ }^{1}$

Semakin meningkatnya angka karies gigi saat ini dipengaruhi oleh antara lain perilaku masyarakat. Sebagian besar ma- 
syarakat tidak menyadari pentingnya merawat kesehatan mulut dan gigi. ${ }^{2}$ Ketidaktahuan masyarakat tersebut yang mengakibatkan penurunan produktivitas karena pengaruh nyeri yang dirasakan yang disebabkan karena menurunnya jaringan pendukung gigi. ${ }^{3}$

Karies gigi dapat menjadi sumber infeksi yang mengakibatkan beberapa penyakit sistemik. Pada karies gigi, infeksi mengenai jaringan keras gigi sehingga terjadi kerusakan jaringan keras setempat. Proses terjadinya kerusakan pada jaringan keras gigi melalui suatu reaksi kimiawi yang diperantarai oleh bakteri, yang dimulai dengan proses kerusakan pada bagian anorganik, kemudian berlanjut pada bagian organik. ${ }^{4}$ Bakteri berperan penting pada proses terjadinya karies gigi dan penyakit periodontal. Tanpa adanya bakteri maka karies gigi dan penyakit periodontal tidak dapat terjadi. Salah satu spesies bakteri yang dominan dalam mulut yaitu bakteri Streptococcus mutans (S. mutans). Jenis bakteri ini diketahui merupakan bakteri penyebab utama timbulnya karies gigi. ${ }^{5}$

Telah banyak penelitian yang membuktikan adanya korelasi positif antara jumlah bakteri $S$. mutans pada plak gigi dengan prevalensi karies gigi; oleh karena itu bakteri ini telah menjadi target utama dalam upaya mencegah terjadinya karies gigi dan penyakit periodontal. ${ }^{6}$ Penelitian dengan memanfaatkan bahan alam telah banyak dilakukan dan kesemuanya bertujuan untuk menghasilkan obat-obatan dalam upaya mendukung program pelayanan kesehatan gigi. Tanaman tersebut dikenal sebagai tanaman obat tradisional atau obat herbal. Salah satu tanaman yang memiliki khasiat obat ialah kembang sepatu (Hibiscus rosa-sinensis L.). ${ }^{7}$

Tanaman kembang sepatu (Hibiscus rosa-sinensis L.) merupakan tanaman semak dari famili Malvaseae yang banyak dimanfaatkan sebagai tanaman hias, tanaman pagar, dan bunga potong. Keindahan pada variasi kembang sepatu menjadikannya dikenal sebagai queen of flower. ${ }^{10}$ Penyebaran tanaman kembang sepatu di daerah tropis dan sub tropis menjadikannya memiliki beberapa nama lokal. Selain itu, tanaman ini dikenal dengan sebutan yang berbeda-beda di setiap negara seperti shoeblack plant atau red hibiscus oleh masyarakat Amerika, akabana oleh masyarakat Jepang, aute oleh suku Samoa, kanyanga oleh masyarakat Filipina, dan kembang sepatu oleh masyarakat Indonesia. $^{11}$

Di Indonesia, tanaman ini juga memiliki nama yang berbeda disetiap daerah yaitu bunga roja (Aceh), bungabunga (Batak Karo), soma-soma (Nias), Bekeju (Mentawi), kembang wera (Sunda), kembang sepatu atau wora wari (Jawa), bunga rebong (Madura), embuhanga (Sangir), bunga cepatu (Timor), waribang (Bali), ulange (Gorontalo), ubu-ubu (Ternate), kulango (Buol), dan bunga sepatu (Sulawesi Utara). ${ }^{12}$

Berdasarkan hasil skrining fitokimia yang dilakukan dalam penelitian sebelumnya, ekstrak bunga kembang sepatu memiliki beberapa kandungan senyawa kimia seperti alkaloid, glikosida, flavonoid, tanin, fenol, dan saponin. ${ }^{8}$ Flavonoid yang terdapat pada bunga kembang sepatu berfungsi sebagai antibakteri karena mengandung gugus fenol yang dapat menyebabkan denaturasi protein dan merusak membran sel sehingga menghambat pertumbuhan bakteri. $^{9}$

Berdasarkan uraian tersebut, penulis tertarik untuk melakukan penelitian mengenai uji daya hambat ekstrak bunga kembang sepatu (Hibiscus rosa-sinensis L.) terhadap pertumbuhan bakteri Streptococcus mutans. Uji daya hambat ekstrak bunga kembang sepatu terhadap partumbuhan bakteri Streptococcus mutans belum pernah dilaporkan. Penggunaan bagian bunga kembang sepatu dikarenakan adanya data empiris yang menerangkan bahwa bunga tanaman ini memiliki kandungan senyawa yang dapat menghambat partumbuhan bakteri. Kandungan senyawa kimia yang bersifat antibakteri dalam ekstrak bunga sepatu diharapkan dapat menghambat pertumbuhan bakteri Streptococcus mutans dan dapat dijadikan penunjang dalam terapi karies. 


\section{METODE PENELITIAN}

Penelitian ini dilakukan di Laboratorium Mikrobiologi Fakultas Kedokteran dan Laboratorium Farmasi Fakultas MIPA Universitas Sam Ratulangi Manado. Subjek penelitian ialah bakteri Streptococcus mutans. Jenis penelitian ini ialah eksperimental laboratorik secara in vitro, menggunakan rancangan eksperimental murni (true experimental design) dengan post-test only control group design.

Semua alat disterilkan dalam oven pada suhu $170^{\circ} \mathrm{C}$ selama 1 jam dan media disterilkan menggunakan autoklaf pada suhu $121^{\circ} \mathrm{C}$ selama 15 menit. Bunga kembang sepatu (Hibiscus rosa-sinensis L.) diperoleh dari daerah Kotamobagu, Sulawesi Utara (Gambar 1). Ekstrak bunga kembang sepatu dibuat menggunakan teknik maserasi dengan pelarut etanol $96 \%$. Ekstrak murni dari bunga kembang sepatu dimasukkan ke dalam oven selama 2 jam dengan suhu $40^{\circ} \mathrm{C}$ kemudian dituang ke dalam botol kaca steril tertutup dan disimpan dalam lemari es.

Bakteri Streptococcus mutans yang digunakan dalam penelitian ini berasal dari stok murni bakteri Streptococcus mutans dari Laboratorium Mikrobiologi Fakultas Kedokteran Universitas Sam Ratulangi Manado. Medium Nutrien Agar (NA) sebanyak 23 gr dilarutkan dengan 1 liter akuades menggunakan tabung Erlenmeyer, kemudian dihomogenkan dan dituang kedalam cawan Petri. Media NA dibiarkan pada suhu ruangan selama 30 menit sampai media mengeras. Kemudian Media NA dimasukkan kedalam autoklaf untuk disterilkan selama 15 menit pada suhu $121^{\circ} \mathrm{C}$ dengan tekanan 1 atm. MullerHinton Agar (MHA) ditimbang sebanyak 38 gram menggunakan 1 liter aquades sebagai pelarut. Media disterilisasi dalam autoklaf pada suhu $121^{\circ} \mathrm{C}$ selama 15 menit, selanjutnya dimasukkan ke dalam cawan Petri sebanyak $10 \mathrm{ml}$ dan dibiarkan hingga mengeras. Lapisan berikutnya dituang media yang sama sebanyak $20 \mathrm{ml}$. Larutan baku Mc Farland terdiri atas dua komponen yaitu 0,5 ml larutan $\mathrm{BaCl} 21 \%$ dan 9,5 ml $\mathrm{H} 2 \mathrm{SO} 41 \%$ dan dikocok homogen sampai terbentuk larutan yang keruh. Nilai absorban larutan baku harus berada di kisaran 0,08 sampai dengan 0,13. Larutan baku Mc Farland 0,5 ekuivalen dengan suspensi sel bakteri dengan konsentrasi $1,5 \times 10^{8} \mathrm{CFU} / \mathrm{ml}$. Kekeruhan ini akan dipakai sebagai standar suspensi bakteri uji. Kontrol positif menggunakkan disc/cakram Eritromisin $32 \mu \mathrm{g} / \mathrm{ml}$ sedangkan kontrol negatif menggunakan akuades steril.

Data perhitungan hasil diameter zona hambat pada setiap bahan coba diukur melalui nilai rerata. Data yang sudah diolah disajikan dalam bentuk tabel, tulisan, dan gambar. Perhitungan dilakukan dengan menggunakan program komputer. Hasil pengukuran diameter zona hambat diklasifikasikan berdasarkan respon hambatan pertumbuhan menurut Davis dan Stout.

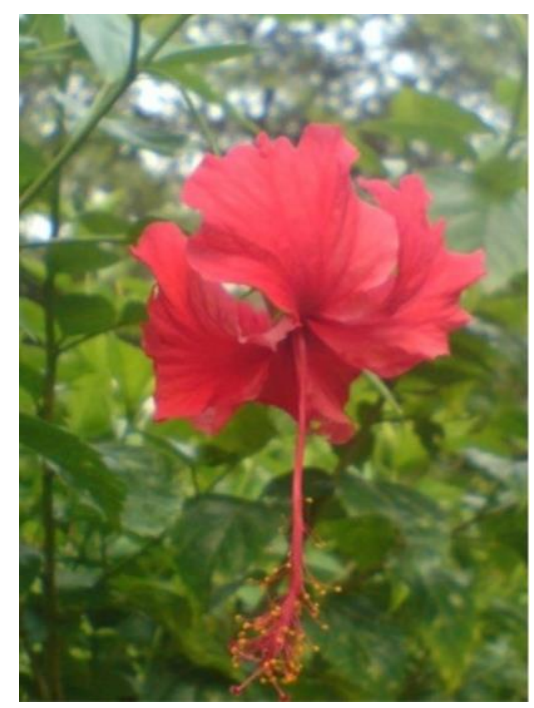

Gambar 1. Bunga kembang sepatu (Hibiscus rosa-sinensis L.) diambil dari daerah Kotamobagu, Sulawesi Utara

\section{HASIL PENELITIAN}

Pengujian daya hambat dilakukan dengan mengukur zona hambat pada media MHA yang telah digores dengan bakteri Streptococcus mutans pasca inkubasi dalam alat inkubator selama 24 jam pada suhu $37^{\circ} \mathrm{C}$. Pertumbuhan bakteri setelah inkubasi terlihat menjauhi cakram, yang artinya terdapat pembentukan zona hambat di sekitar kertas cakram yang telah dijenuhkan dengan ekstrak bunga kembang sepatu dan pada cakram antibiotik eritromisin. Pada 
cakram yang dijenuhkan dengan akuades steril tidak terlihat adanya zona hambat.

Zona hambat yang terbentuk di sekitar cakram diukur diameternya dengan menggunakan jangka sorong. Pengukuran dilakukan dengan cara mengukur diameter horizontal dan diameter vertikal, diukur zona bening yang terbentuk di sekitar cakram dari ujung yang satu ke ujung lainnya. Kedua diameter horizontal dan diameter vertikal dijumlahkan kemudian dibagi 2 untuk mencari nilai rerata diameter zona hambat. Tabel 1 memperlihatkan diameter zona hambat yang dihasilkan ekstrak bunga kembang sepatu pada lima cawan Petri yang terbentuk sebesar 23,5 mm dengan nilai rerata $4,6 \mathrm{~mm}$. Tabel 2 memperlihatkan total diameter zona hambat yang dihasilkan oleh eritromisin sebesar $120,5 \mathrm{~mm}$ dengan nilai rerata $24,1 \mathrm{~mm}$. Tabel 3 memperlihatkan bahwa akuades tidak menghasilkan zona hambat dengan nilai total pada lima kali pengulangan yaitu $0 \mathrm{~mm}$.

Tabel 1. Diameter zona hambat yang dihasilkan oleh ekstrak bunga kembang sepatu (dalam mm)

\begin{tabular}{|c|c|c|c|}
\hline \multirow{2}{*}{$\begin{array}{l}\text { Cawan } \\
\text { Petri }\end{array}$} & \multicolumn{3}{|c|}{ Ekstrak bunga kembang sepatu (dalam mm) } \\
\hline & $\begin{array}{l}\text { Diameter } \\
\text { horizontal }\end{array}$ & $\begin{array}{c}\text { Diameter } \\
\text { vertikal }\end{array}$ & $\begin{array}{c}\text { Diameter } \\
\text { zona hambat }\end{array}$ \\
\hline I & 5,0 & 5,0 & 5,0 \\
\hline II & 4,0 & 5,0 & 4,5 \\
\hline III & 5,0 & 5,0 & 5,0 \\
\hline IV & 4,0 & 4,0 & 4,0 \\
\hline $\mathrm{V}$ & 5,0 & 5,0 & 5,0 \\
\hline Total & & & 23,5 \\
\hline Rerata & & & 4,6 \\
\hline
\end{tabular}

Tabel 2. Diameter zona hambat yang dihasilkan oleh eritromisin sebagai kontrol (+)

\begin{tabular}{cccc}
$\begin{array}{c}\text { Cawan } \\
\text { Petri }\end{array}$ & $\begin{array}{c}\text { Eritromisin (kontrol +) (dalam mm) } \\
\text { Diameter } \\
\text { horizontal }\end{array}$ & $\begin{array}{c}\text { Diameter } \\
\text { vertikal }\end{array}$ & $\begin{array}{c}\text { Diameter } \\
\text { zona hambat }\end{array}$ \\
\hline I & 12 & 11 & 11,5 \\
II & 6 & 5 & 5,5 \\
III & 37 & 35 & 36 \\
IV & 34 & 34 & 34 \\
V & 35 & 32 & 33,5 \\
Total & & & 120,5 \\
Rerata & & & 24,1 \\
\hline
\end{tabular}

Tabel 3. Diameter zona hambat yang dihasilkan oleh akuades sebagai kontrol (-)

\begin{tabular}{|c|c|c|c|}
\hline \multirow{2}{*}{$\begin{array}{c}\text { Cawan } \\
\text { Petri }\end{array}$} & \multicolumn{3}{|c|}{ Akuades (kontrol -) (dalam mm) } \\
\hline & $\begin{array}{l}\text { Diameter } \\
\text { horizontal }\end{array}$ & $\begin{array}{c}\text { Diameter } \\
\text { vertikal }\end{array}$ & $\begin{array}{c}\text { Diameter } \\
\text { zona hambat }\end{array}$ \\
\hline I & 0 & 0 & 0 \\
\hline II & 0 & 0 & 0 \\
\hline III & 0 & 0 & 0 \\
\hline IV & 0 & 0 & 0 \\
\hline $\mathrm{V}$ & 0 & 0 & 0 \\
\hline Total & & & 0 \\
\hline Rerata & & & 0 \\
\hline
\end{tabular}


Tabel 4. Perbandingan diameter zona hambat terhadap bakteri Streptococcus mutans

\begin{tabular}{|c|c|c|c|}
\hline \multirow[t]{2}{*}{ Cawan Petri } & \multicolumn{2}{|c|}{ Diameter zona hambat (mm) } & \multirow[b]{2}{*}{$\begin{array}{l}\text { Akuades } \\
\text { (kontrol -) }\end{array}$} \\
\hline & $\begin{array}{l}\text { Ekstrak bunga } \\
\text { kembang sepatu }\end{array}$ & $\begin{array}{c}\text { Eritromisin } \\
(\text { kontrol +) }\end{array}$ & \\
\hline I & 5,0 & 11,5 & 0 \\
\hline II & 4,5 & 5,5 & 0 \\
\hline III & 5,0 & 36 & 0 \\
\hline IV & 4,0 & 34 & 0 \\
\hline $\mathrm{V}$ & 5,0 & 33,5 & 0 \\
\hline Total & 23,5 & 120,5 & 0 \\
\hline Rerata & 4,6 & 24,1 & 0 \\
\hline
\end{tabular}

Tabel 4 memperlihatkan perbandingan diameter zona hambat yang dihasilkan di sekitar cakram dengan berbagai perlakuan. Dari nilai tersebut tampak bahwa terdapat zona hambat yang terbentuk di sekitar cakram yang diberi ekstrak bunga kembang sepatu di setiap pengulangan.

\section{BAHASAN}

Penelitian ini bertujuan untuk mengetahui adanya daya hambat dari ekstrak bunga kembang sepatu terhadap partumbuhan bakteri Streptococcus mutans. Pembiakan bakteri Streptococcus mutans dilakukan dalam media Muler Hinton Agar (MHA), dan diberi 3 kertas cakram. Kelompok intervensi diberi ekstrak bunga kembang sepatu, antibiotik eritromisin sebagai kontrol positif, dan akuades sebagai kontrol negatif kemudian diinkubasi pada suhu $37^{\circ} \mathrm{C}$ selama 24 jam.

Hasil pengamatan yang dilakukan pada lima kali pengulangan di setiap cawan Petri mendapatkan adanya zona hambat yang terbentuk di sekitar cakram yang diberi ekstrak bunga kembang sepatu. Zona hambat tertinggi ditunjukkan pada pengulangan I, III dan V yaitu sebesar 5,0 mm sedangkan zona hambat terkecil ditunjukkan pada pengulangan IV yaitu sebesar 4,0 $\mathrm{mm}$. Diameter zona hambat di sekitar cakram yang dihasilkan ekstrak bunga kembang sepatu mendapatkan nilai rerata sebesar 4,6 mm (Tabel 1).

Hasil pengukuran diameter zona hambat digolongkan berdasarkan klasifikasi zona hambat menurut Davis and Stout.
Ekstrak bunga kembang sepatu mempunyai zona hambat yang tergolong pada kategori lemah dalam menghambat pertumbuhan bakteri Streptococcus mutans. Dibandingkan dengan zona hambat yang terbentuk di sekitar antibiotik Eritromisin, diameter zona hambat ekstrak bunga kembang sepatu lebih kecil. Konsentrasi eritromisin yang digunakan dalam penelitian ini merupakan konsentrasi minimum dari eritromisin dalam menghambat pertum-buhan bakteri anaerob. Zona hambat yang terbentuk di sekitar cakram yang diberi eritromisin tertinggi ditunjukkan pada pengulangan V yaitu sebesar 33,5 mm sedangkan zona hambat terkecil ditunjukkan pada pengulangan II yaitu sebesar $5,5 \mathrm{~mm}$ dan perolehan nilai rerata sebesar $24,1 \mathrm{~mm}$. Pada cakram yang diberi akuades tidak terbentuk zona hambat. Hal tersebut menandakan bahwa tidak terdapat pengaruh akuades pada proses pembuatan media MHA.

Eritromisin adalah antibiotik golongan makrolida berspektrum luas sehingga mampu membunuh bakteri Gram positif maupun negatif. Mekanisme kerja eritromisin dalam mengobati penyakit infeksi yaitu dengan cara menghambat pertumbuhan bakteri (bakteriostatik). Antibiotik ini akan mengikat sub unit 50s dan 70s dari ribosom bakteri sehingga terjadi penghambatan translasi mRNA, dan bakteri tidak dapat menyintesis protein sehingga pertumbuhannya akan terhambat bahkan mati. ${ }^{13}$

Zona hambat yang terbentuk di sekitar cakram ini disebabkan oleh aktivitas 
senyawa yang terkandung dalam ekstrak bunga kembang sepatu. Senyawa-senyawa yang berperan sebagai antibakteri dalam bunga kembang sepatu di antaranya ialah tannin, alkaloid, triterpenoid, sianidin, glikosida, kuersetin, dan diglukosida. ${ }^{2}$ Hasil penelitian ini menunjukkan bahwa ekstrak bunga kembang sepatu mempunyai kandungan dengan daya hambat yang masih tergolong lemah terhadap pertumbuhan bakteri Streptococcus mutans. Hasil penelitian ini didukung oleh penelitian oleh Mak et $\mathrm{al}^{14}$ yang menyatakan ekstrak bunga kembang sepatu dapat menghambat pertumbuhan bakteri Salmonella thypirium, Staphylococcus aureus, Bacillus cereus, Klebsiella pneumonia. Demikian pula penelitian oleh Rendeng et $\mathrm{al}^{15}$ mendapatkan ekstrak bunga kembang sepatu dapat menghambat pertumbuhan dan membunuh Mycobacterium tuberculosis.

\section{SIMPULAN}

Ekstrak bunga kembang sepatu (Hibiscus rosa-sinensis L.) memiliki daya hambat terhadap pertumbuhan bakteri Streptococcus mutans yang tergolong lemah.

Bagi peneliti lanjut, disarankan untuk mendapatkan konsentrasi hambat minimum dan konsentrasi bunuh minimum dari ekstrak bunga kembang sepatu dan mengevaluasi secara in vivo dosis, efek toksisitas, dan efek samping dari ekstrak bunga kembang sepatu (Hibiscus rosa sinensis $\mathrm{L}$ ).

\section{Konflik Kepentingan}

Penulis menyatakan tidak terdapat konflik kepentingan dalam studi ini.

\section{DAFTAR PUSTAKA}

1. Badan Penelitian dan Pengembangan Kesehatan. Riset kesehatan dasar riskesdas 2018. Jakarta: Kementerian Kesehatan RI.2018; p. 94.

2. Tjahja IN. Hubungan kebersihan gigi dan mulut dengan pengetahuan dan sikap responden di beberapa puskesmas di propinsi Jawa Barat. Media Litbang Kesehatan. 2005;15(4):1-7.
3. WHO Epidemiology: Etiology and prevention of periodontal diseases. Technical Report Series no. 621 Geneva: World Health Organization, 1978; p.1-7.

4. Departemen Kesehatan RI. 2010. Profil Kesehatan Indonesia 2010. [cited 2010 July 16]. Available from: http://www. depkes.go.id/downloads/PROFIL_KES EHATAN_INDONESIA_2010.pdf.

5. Nurhidayat $O$, Tunggul EP, Wahyono $B$. Perbandingan media power point dengan flip chart dalam meningkatkan pengetahuan kesehatan gigi dan mulut. Unnes Jopurnal of Public Health. 2012; 1(1):31-5.

6. Lundeer TF, Roberson TM, Carrology: The lesion, etiology, prevention, and control. In: Sturdevant CM, Roberson TM, Heymann HO, Sturdevant JR, editors. The Art and Science of Operative Dentistry (3th ed). St. Louis: TaosbyYear Book Inc, 1995; p. 62.

7. Lavelle CLB. Applied Oral Physiology (2nd ed). London: Wright, 2006; p. 96-7.

8. Roeslan OB. Karakteristik Streptococus mutans penyebab karies gigi. Majalah Ilmiah Kedokteran Gigi Fakultas Kedokteran Gigi USAKTI. 2007;29-30 (10);112-5.

9. Samsumaharto RA, Hartanto SD. Uji aktivitas antibakteri ekstrak n-heksan, etil asetat dan etanol 70\% daun kembang sepatu (Hibiscus rosa-sinesis L) terhadap S. aureus ATCC 25923 [Laporan penelitian]. Surakarta: Universitas Setia Budi; 2010.

10. Kinho J, Arini DID. Tumbuhan Obat Tradisional di Sulawesi Utara, Jilid 1. Manado: Kementerian Kehutanan, 2011; p. 44-6.

11. Triwari U, Yadav P. Nigam D. Study on phytochemical screening and antibacterial potential of methanolic flower and leaf extracts of Hibiscus rosa sinensis. International Journal of Innovative and Applied Research. 2015;3(6):9-14.

12. Beers CL, Howie J. Growing Hibiscus. 1990: $5 \mathrm{hlm}$. [cited 2016 May 5]. Available from: http://www.hibiscusworld.com/ BeersBook/Intro.htm.

13. Rahman IR, Kusumowati ITD, Indrayudha $P$, Sukmawati A. Uji stabilitas fisik dan daya antibakteri suspense eritromisin dengan suspending agent pulvis gummi 
14 e-GiGi, Volume 8 Nomor 1, Januari-Juni 2020, hlm. 8-14

arabici. Jurnal Pharmacon. 2011:12(2):

44-9.

14. Mak YW, Chuah LO, Ahmad R, Bhat R. Antioxidant and antibacterial activities of hibiscus (Hibiscus rosa-sinensis L.) and Cassia (Senna bicapsularis L.) flower extracts. Journal of King Saud
University-Science. 2013;25:275-82.

15. Rendeng EF, Kepel BJ, Manampiring AE. Uji anti mycobacterium ekstrak bunga kembang sepatu (Hibiscus rosa sinensis L.) sebagai tumbuhan obat anti tuberculosis. Jurnal Biomedik. 2020; 12(1):48-53. 